This PDF is a selection from a published volume from the National Bureau of Economic Research

Volume Title: Tax Policy and the Economy, Volume 19

Volume Author/Editor: James M. Poterba, editor

Volume Publisher: MIT Press

Volume ISBN: 0-262-16236-9

Volume URL: http://www.nber.org/books/pote05-1

Conference Date: October 7, 2004

Publication Date: September 2005

Title: Book-Tax Conformity for Corporate Income: An Introduction to the Issues

Author: Michelle Hanlon, Terry Shevlin

URL: http://www.nber.org/chapters/c0166 


\title{
Book-Tax Conformity for Corporate Income: An Introduction to the Issues
}

\author{
Michelle Hanlon, University of Michigan \\ Terry Shevlin, University of Washington
}

\section{Executive Summary}

This paper discusses the issues surrounding the proposals to conform financial accounting income and taxable income. The two incomes diverged in the late 1990s, with financial accounting income becoming increasingly greater than taxable income through the year 2000. While the cause of this divergence is not known for certain, many suspect that it is the result of earnings management for financial accounting and/or the tax sheltering of corporate income. Our paper outlines the potential costs and benefits of one of the proposed "fixes" to the divergence: the conforming of the two incomes into one measure. We review relevant research that sheds light on the issues surrounding conformity both in the United States as well as evidence from other countries that have more closely aligned book and taxable incomes. The extant empirical literature reveals that it is unlikely that conforming the incomes will reduce the amount of tax sheltering by corporations and that having only one measure of income will result in a loss of information to the capital markets.

\section{Introduction}

This paper discusses the issues surrounding the proposal to conform financial accounting (book) income and taxable income. We review recent literature that sheds light on this proposal in order to inform the policy debate regarding what to do about the current divergence between financial accounting and taxable incomes. The expanding divergence between book and taxable incomes has attracted much attention and analysis in recent years (e.g., Plesko, 2002; Desai, 2003; Mills et al., 2002). The real concern with diverging book and tax incomes is not 
that they are different per se, but that the difference may be caused by some misleading or even fraudulent activity on the part of firms in reporting book income, taxable income, or both. ${ }^{1}$ While there is little debate that the incomes are diverging, the cause of the divergence and whether and how to fix it are very much open questions. One proposal to fix the system is to conform the financial accounting (book) and taxable income numbers. For example, Yin (2001), in response to the Treasury's white paper entitled "The Problem with Corporate Tax Shelters," claims that one way to solve the "problem" is to tax public corporations on their income reported for financial reporting purposes, as adjusted by tax rules authorizing specific deviations from that base (p. 26). Further, Desai (2004) argues that the dual reporting of corporate income has led to a degradation of corporate profit reporting and "conforming the measurement of book and tax profits could provide firms with some automatic incentives to reduce tax avoidance and to be less aggressive in reporting profits to capital markets" (p. 3). Our paper reviews much of the literature in this area, provides an overview of book-tax differences and their disclosure, discusses the proposed "solutions" to the "problem," and most specifically discusses the issues surrounding conforming financial accounting income and taxable income to one measure.

Regulators, academics, and the press have proposed three solutions regarding the increasing divergence between the two incomes. ${ }^{2}$ The first is to require firms to disclose their entire tax return so that investors can compare the two sets of reports and from this comparison arrive at a more accurate measure of performance for the firm. The second suggestion is to have firms disclose only certain items from the tax return, such as the amount of taxable income and tax liability, because currently the financial statements do not include this information. ${ }^{3}$ The third proposal is to conform the two incomes; that is, eliminate the book-tax differences that exist under the current system. Prior literature has discussed the first two proposals in detail. Lenter, Shackelford, and Slemrod (2003; hereafter LSS) argue that the case for disclosure of the entire tax return is unappealing because it could cause companies to dilute the information on the tax return, thus hampering tax enforcement. In addition, disclosing the entire return may reveal proprietary information and otherwise private business information to the firm's competitors. ${ }^{4}$ LSS argue that the case for limited disclosure of tax return information (such as bottom line taxable income or a more detailed reconciliation between book and taxable incomes) is more 
compelling because it could contribute to the transparency of the tax system. Our paper focuses mainly on the third proposal-the conforming of book and taxable incomes. ${ }^{5}$

In sum, there are both potential benefits and potential costs of conforming the two measures of income. For example, in terms of potential benefits, it is likely that corporations would incur less compliance cost in terms of reporting because they would report (essentially) the same measure to both the Internal Revenue Service (IRS) and the Securities and Exchange Commission (SEC). Further, many argue that the temptation on the part of executives to mislead/lie for either financial accounting or taxable income purposes would be significantly reduced or even eliminated. Executives would be less inclined to overstate financial accounting income because this would result in higher taxes, and they would not want to understate taxable income because this would result in lower income reported to creditors and shareholders. Finally, conforming the incomes would likely simplify a currently very complex reporting environment where both investors and the Treasury are left to decipher how a firm can report stunning profits to investors yet show losses on their tax return. ${ }^{6}$

However, there are many potential costs to be considered as well. An important one, which is often overlooked, is the loss of information to the capital markets. Clearly, however, this depends on how the conforming of the incomes is accomplished. For example, would financial accounting income be conformed to tax or would taxable income be conformed to financial accounting? We believe that the latter is unlikely because Congress would then be leaving the Treasury's revenue determination in the hands of the private sector Financial Accounting Standards Board (FASB). As further support of this claim, we point to the recent controversy over stock option expensing (which we discuss further below); Congress involved itself in this issue with no tax revenue implications, indicating it is unlikely to relinquish control over items concerning tax revenues to another body. Another alternative is just to reduce significantly the number of book-tax differences allowed (Yin 2001). Consistent with the work by George Stigler (1971), which provides that regulators are often captured by the regulated enterprises, promoting the interests of the firms instead of the common good, we conjecture that with this proposal it is likely that additional differences would soon be added to please every special interest group and constituency and, as a result, we would soon be back to a system with innumerable adjustments. Thus, if the two incomes were 
conformed, the conformed number reported would be (or approach) taxable income as defined under the current system. If that is the case, then the current financial accounting measure of performance would not be available to the markets, and recent research finds that a loss of value-relevant information would occur.

In addition, there is no assurance provided by current research that conforming the incomes would in fact reduce the amount of tax sheltering. If all participants know that the income reported is that on which the firm's tax is computed, it will no longer be relied upon as heavily as a performance measure. ${ }^{7}$ As a result, management will not want to overstate the amount and will want to understate it only in order to reduce the tax liability and maximize after-tax cash flows to increase shareholder value. ${ }^{8}$ Thus, while likely preventing financial accounting overstatement on the part of management, tax sheltering would still occur and a minimized income number will not convey the desired information regarding performance to shareholders.

We develop these ideas as follows. Section 2 describes how taxable income and financial accounting income are currently computed, the differences between the two incomes, and how these differences are disclosed. Section 3 discusses the recent divergence between book and taxable income. Section 4 provides an overview of the proposed "solutions" for correcting this divergence. Section 5 covers in detail the issues specifically surrounding one proposed solution-conforming book and taxable incomes to one measure-including evidence from international settings, evidence on how the market uses the two income measures, and some further thoughts on a system of partial conformity. Section 6 concludes.

\section{Book and Taxable Income: How They are Calculated and How They are Different}

Management calculates corporate income for two external purposes each year. The first is for financial reporting purposes under Generally Accepted Accounting Principles (GAAP) and the second in accordance with the Internal Revenue Code (IRC) to determine the corporation's tax liabilities. Financial accounting income is intended to provide outside stakeholders (e.g., investors, creditors, regulators, etc.) with information about firm performance. In contrast, the objectives of the IRC are to provide a framework for efficient and equitable determination of tax liabilities and the subsequent collection of revenue; to provide incentives for firms to engage in, or not engage in, particular activities; 
and to reward particular constituencies (Scholes, Wolfson, Erickson, Maydew, and Shevlin, 2002; Manzon and Plesko, 2002).

Despite both book and taxable income being prepared on an accrual basis, differences between book and taxable incomes can be large. ${ }^{9}$ Some differences, known as permanent differences, are items included in one measure of income but never included in the other. ${ }^{10}$ The simplest example is municipal bond interest, which is included in financial accounting income but is excluded from taxable income.

Other book-tax differences are temporary. Temporary differences arise because of differing requirements for the timing of recognition of income and expense items. For book purposes, revenue is recognized when earned, and expense recognition is either matched against the related revenue or recorded in the accounting period in which the expense is incurred. For tax purposes, however, firms must "clearly reflect income." 11 Revenue is generally recorded when cash is received and expenses may not be deducted until more stringent conditions are satisfied, reducing the level of discretion in the calculation of taxable income.

The simplest example of a temporary difference is depreciation. For tax purposes, a firm depreciates its assets using the modified accelerated cost recovery system (MACRS) method, which allows the writeoff of an asset at a much faster rate than the most commonly used method for financial accounting, straight-line depreciation. Another example is bad debt expense. Under GAAP, firms are required to estimate the proportion of sales that will ultimately become uncollectible and expense this amount in the same period as the recognition (inclusion) of the sale in revenue, thus reducing profits and the associated asset account to estimated net realizable value. For tax purposes, however, firms are required to use the specific write-off method and thus cannot deduct the estimated expense associated with the earned revenue but must wait until a specific receivable is known to be uncollectible before it can be written off (deducted). Similarly, for financial accounting purposes, firms must estimate the cost associated with warranties and record this expense in the same period as the associated sale (thus, matching the expense with the revenue). For tax purposes, however, estimates of future expenses cannot be deducted. The firm must wait until the warranty claims are fulfilled before the deduction can be taken.

Book-tax differences are disclosed to some extent on both the tax return and in the firm's financial statements. A firm must reconcile its financial accounting income to its taxable income on Schedule M-1 of 
its tax return. However, because the M-1 was not thought to provide sufficient detail for the IRS to clearly tell why taxable income differed from financial reporting income, a new Schedule $M-3$ is required for corporate tax returns filed for any taxable year ending on or after December $31,2004 .{ }^{12}$ Neither the M-1 nor the M-3 is publicly available. ${ }^{13}$

Firms are also required to disclose their material book-tax differences in the notes to their financial statements. The temporary book-tax differences are disclosed through the listing of the changes in material deferred tax assets and deferred tax liabilities, and the permanent differences are disclosed in the reconciliation of the statutory tax rate to the firm's effective (average) tax rate. While a detailed discussion of these disclosures is beyond the scope of this paper, the overall value of the disclosures in the financial statements is extremely limited because only the very large differences are listed, the descriptions are generally vague, and the description for the same item can vary substantially across firms. In addition, it is important to note that the tax provision on a firm's income statement does not equal the taxes paid by the firm. Further, the actual tax liability of the firm is not publicly disclosed; it can be estimated but with the potential for measurement error (see Hanlon, 2003, for more information on the problems with the tax note contained in financial statement disclosures). ${ }^{14}$

In summary, there are clear reasons why book and taxable incomes are different, most notably because the incomes are not intended to serve the same purpose. Financial accounting income is intended to provide information regarding firm performance to the marketplace, while taxable income is prescribed by the government to meet budgetary needs and to provide incentives (disincentives) for desired (undesired) behavior. There are many items that can cause taxable income to differ from book income. Some differences are permanent in nature and some are temporary, meaning the effect of the difference will reverse in the future. Finally, because of limited disclosures, investors and the IRS both have difficulty determining why taxable income is different than book income.

\section{The Divergence between Book and Taxable Incomes}

Many studies have concluded that the difference between book and taxable incomes was increasing throughout the late 1990s (we discuss these below). The divergence per se is not a concern, but what is a concern is that the cause of this divergence is unknown. The speculation 
is that it is caused by firm managers manipulating both incomes to achieve the best of both worlds: a high reported financial accounting income to shareholders and creditors designed to boost market value, and a low reported taxable income designed to boost cash flows (by lowering tax payments) and reported financial accounting earnings (due to a lower tax expense). ${ }^{15}$

This divergence has been measured and analyzed in a variety of ways yet all studies reach very similar conclusions. One early analysis was done by the U.S. Department of the Treasury (1999). The Treasury examined Schedule M-1 reconciliations of book to taxable income and concluded that the evidence "suggests that the difference between book income and taxable income has increased recently" (p. 32). They calculate a ratio of aggregate pre-tax book income to aggregate taxable income and find that this ratio was 1.82 in 1995 and 1.86 in 1996, both of which are substantially above the average of 1.25 during the 19901994 period. In Figure 1, we include a copy of a Treasury graph showing this increasing book-tax gap between 1992 and 1996.

These Treasury results have been replicated with publicly available data (Plesko, 2000; Manzon and Plesko, 2002; Desai, 2003) and extended with tabulated tax return data (Mills et al., 2002; Plesko, 2002; Plesko, 2004). The results of these studies agree with those of the Treasury-the difference between book and taxable incomes increased

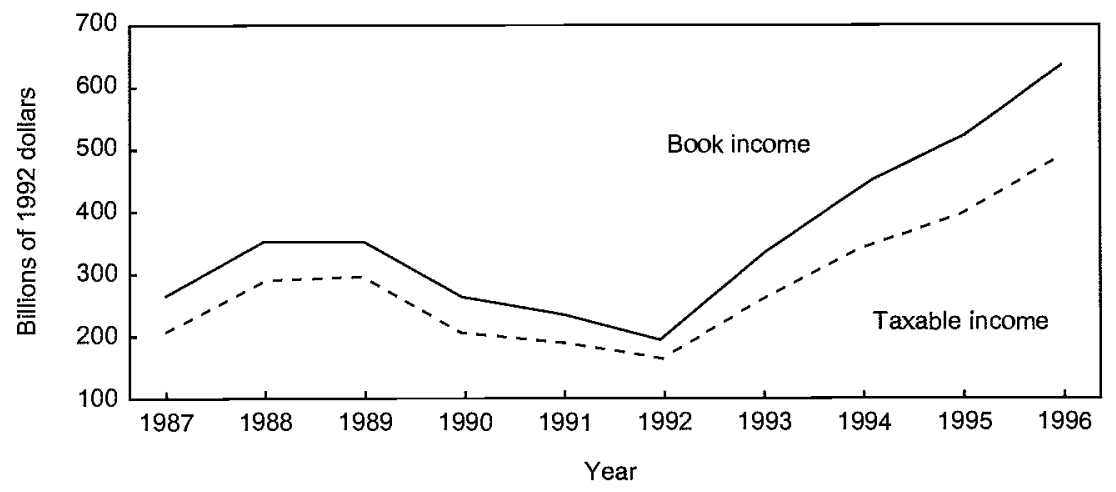

Figure 1

Book Income Versus Taxable Income for Corporations with More Than \$1 Billion in Assets

Pre-tax book income is defined as after-tax book income plus federal taxes, as reported on lines 1 and 2 of Schedule $M$.

From U.S. Department of the Treasury (1999). 


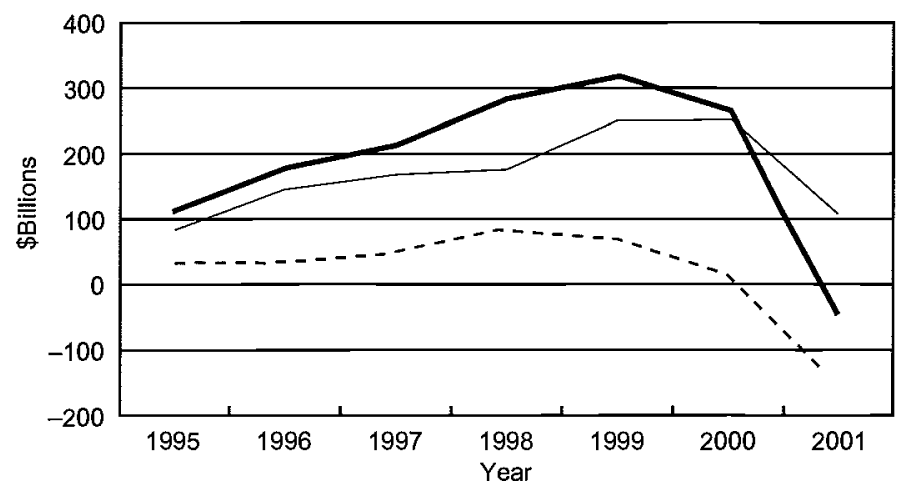

Firms with net income

- - - Loss firms

All firms

Figure 2

Book-Tax Reporting Differences, 1995-2001

From Plesko (2004).

in the late 1990s. We have included a figure from Plesko (2004) showing the book-tax gap (see Figure 2).

Yin (2003) evaluates the validity of the concerns over the book-tax gap by calculating effective tax rates (defined in Yin, 2003, as current tax expense/pre-tax book income) and examines these rates over time for the S\&P 500. Yin argues that many of the measures used in the prior studies may not be meaningful for corporations with significant foreign investment and are confounded by the potentially large booktax difference created by the exercise of non-qualified stock options. Thus, Yin (2003) uses a different measure, the effective tax rate, but finds very similar results. He finds that the effective tax rates of the S\&P 500 firms fell, on average, almost steadily throughout the six-year period 1995-2000, from 28.85 percent in 1995 to 24.20 percent in 2000. After adjusting for the effect of the large book-tax difference created by the exercise of non-qualified stock options, he finds that the effective tax rates of the sample decreased from 30.11 percent in 1995 to 27.98 percent in 2000, a 7.1 percent decline.

Also using a measure of tax liability to total income, the U.S. General Accounting Office (GAO) reports that 94 percent of U.S. controlled corporations and 89 percent of foreign controlled corporations reported tax liabilities of less than 5 percent of their total income. The GAO found similar results for large corporations (defined as those with at least $\$ 250$ million in assets or $\$ 50$ million in gross receipts). ${ }^{16}$ 
Table 1

Pre-Tax Book Income (PTBI) and Estimated Taxable Income (TI) from 1985 to 2003

\begin{tabular}{llrrr}
\hline Year & PTBI & \multicolumn{1}{c}{ TI } & Difference & \multicolumn{1}{l}{$\begin{array}{l}\text { Ratio of } \\
\text { PTBI/TI }\end{array}$} \\
\hline 1985 & $\$ 138,904$ & $\$ 99,868$ & $\$ 39,036$ & 1.39 \\
1986 & $\$ 130,162$ & $\$ 80,622$ & $\$ 49,539$ & 1.61 \\
1987 & $\$ 167,736$ & $\$ 137,019$ & $\$ 30,716$ & 1.22 \\
1988 & $\$ 191,108$ & $\$ 188,720$ & $\$ 2,388$ & 1.01 \\
1989 & $\$ 191,130$ & $\$ 184,844$ & $\$ 6,286$ & 1.03 \\
1990 & $\$ 192,730$ & $\$ 198,181$ & $-\$ 5,450$ & 0.97 \\
1991 & $\$ 147,180$ & $\$ 180,259$ & $-\$ 33,078$ & 0.82 \\
1992 & $\$ 162,516$ & $\$ 175,495$ & $-\$ 12,979$ & 0.93 \\
1993 & $\$ 187,691$ & $\$ 204,951$ & $-\$ 17,261$ & 0.92 \\
1994 & $\$ 279,280$ & $\$ 244,924$ & $\$ 34,357$ & 1.14 \\
1995 & $\$ 325,822$ & $\$ 285,528$ & $\$ 40,294$ & 1.14 \\
1996 & $\$ 370,463$ & $\$ 327,303$ & $\$ 43,160$ & 1.13 \\
1997 & $\$ 383,911$ & $\$ 361,882$ & $\$ 22,029$ & 1.06 \\
1998 & $\$ 355,245$ & $\$ 345,330$ & $\$ 9,915$ & 1.03 \\
1999 & $\$ 444,745$ & $\$ 386,256$ & $\$ 58,489$ & 1.15 \\
2000 & $\$ 486,431$ & $\$ 450,564$ & $\$ 35,867$ & 1.08 \\
2001 & $\$ 125,049$ & $\$ 316,144$ & $-\$ 191,095$ & 0.40 \\
2002 & $\$ 229,551$ & $\$ 246,048$ & $-\$ 16,497$ & 0.93 \\
2003 & $\$ 462,055$ & $\$ 305,708$ & $\$ 156,347$ & 1.51 \\
\hline A11 & & & & \\
\hline
\end{tabular}

All amounts are in millions. PTBI is pre-tax book income and is derived by deducting minority interest (Compustat data item 49) from pre-tax book income (data item 170). TI is estimated taxable income and is estimated by summing current federal income tax expense (Compustat data item 63) and current foreign tax expense (data item 64) to derive current tax expense, which is then divided by the top U.S. statutory tax rate applicable to that data year. From that result, we subtract the change in net operating loss (NOL) carryforwards. More specifically, TI is estimated as [(current federal + current foreign income tax expense)/str] $-\Delta \mathrm{NOL}$, where str is the top statutory tax rate applicable to that data year. If federal current tax expense is missing, we use total current tax expense (data items 16-50) rather than the sum of federal and foreign current tax expense. Difference is calculated as PTBI less TI.

To further verify and, more important, to update this book-tax gap through 2003, we present data based on financial statement information showing book and estimated taxable incomes over time in Table 1 and in Figures 3 and $4 .{ }^{17}$ The sample is taken from the merged dataset of the Compustat and Center for Research in Security Prices databases. We exclude financial institutions (Standard Industrial Classification codes 6000-6999) and utilities (SIC codes 4900-4999) because they operate in highly regulated industries and face a different set of tax and/ 


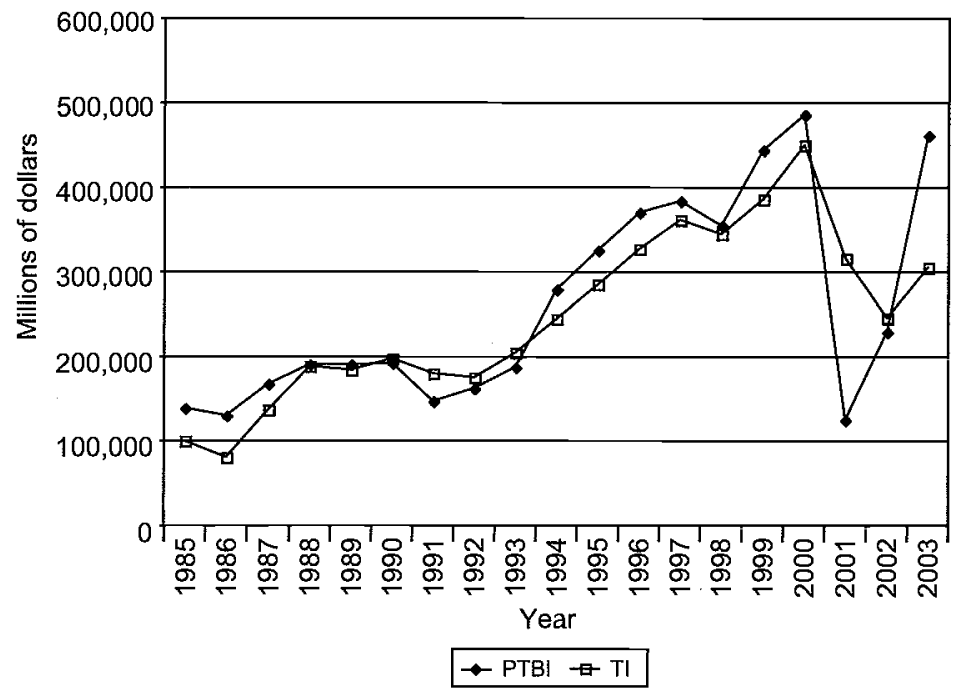

Figure 3

Graph of Pre-tax Book Income and Estimated Taxable Income, 1985-2003 See Table 1 for variable definitions.

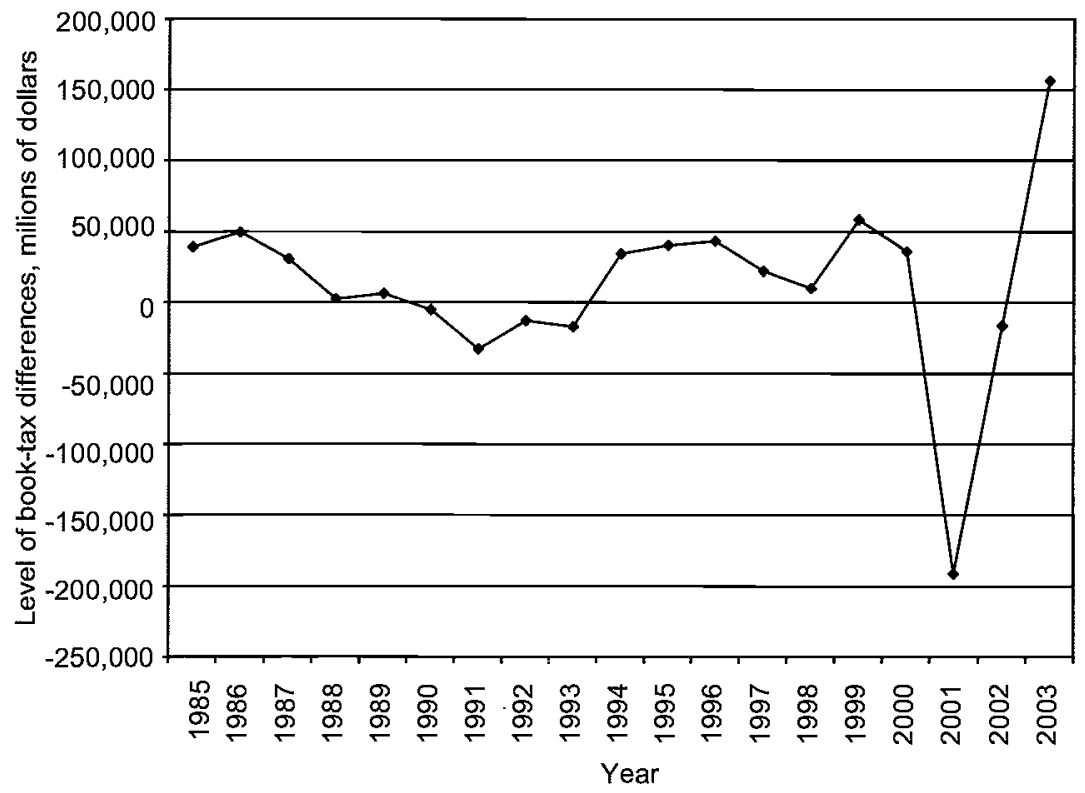

Figure 4

Graph of the Level of Book-Tax Differences, 1985-2003

See Table 1 for variable definitions. 
or book rules than other firms. We also eliminate non-U.S. corporations and any firm-year observation in which the fiscal year changes in order to insure that observations are comparable across years. Our measure of financial accounting income is pre-tax book income. Our measure of taxable income is estimated by summing current federal income tax expense (Compustat data item 63) and current foreign tax expense (data item 64) to derive current tax expense, which is then divided by the top U.S. statutory tax rate applicable to that data year, from which result we subtract the change in net operating loss carryforwards. ${ }^{18}$

Table 1 shows the aggregate amounts of pre-tax book income and estimated taxable income for the sample. In addition, the fourth column provides the difference between the two income measures. ${ }^{19}$ The final column is the ratio of pre-tax book income to taxable income, analogous to the ratio used by the Treasury in its 1999 report on tax shelters. While this ratio shows considerable variation over time, in general one can see that it is higher in the late 1990s than in the early part of the decade. The ratio then decreases significantly in 2001 and 2002 before increasing again in 2003. Figures 3 and 4 present the data in Table 1 in graphical form.

Overall, the data reveal that the aggregate book-tax difference turns positive (aggregate book income is greater than aggregate estimated taxable income) in 1994 and peaks in 1999. In the year 2001, the aggregate book-tax difference is markedly negative; that is, aggregate book income is actually less than aggregate estimated taxable income, which is consistent with results reported by Hanlon, Kelley, and Shevlin (2005; hereafter HKS) and Plesko (2004). HKS find that the negative book-tax difference is due to large negative special items (totaling $\$ 267,847$ million for the sample). ${ }^{20}$ Likewise, Plesko (2004) reports that the aggregate negative book-tax difference in his results is driven by loss firms (see our Figure 2). However, the difference in 2003 becomes positive again and in fact is at its highest level since 1986. While this may indicate that 2001 was likely an anomaly and the overall trend is an increasing one, future analysis will be required as it is difficult to interpret the increase in only one year.

Thus, there seems to be little debate that a large book-tax gap exists in the post Tax Reform Act of 1986 years, especially in the late 1990s. What there is disagreement about is the cause(s) of this increase and what, if anything, to do about it. For example, Yin (2003) states that it is uncertain whether the divergence is caused by firms simply making greater use of known provisions creating book-tax differences or if 
firms "increasingly overstated the amounts of their book income or understated the amounts of their tax liability (whether due to tax shelters or other causes)" (p. 1798). Manzon and Plesko (2002) are also noncommittal in their conclusions after attempting to model and explain firms' book-tax differences. ${ }^{21}$ They state that they "interpret any unexplained residual as attributable to other factors, one of which may be tax shelter activity" (p. 177). Desai (2003) examines the divergence between book and taxable incomes and traces the discrepancy to the differential treatment of depreciation, the reporting of foreign source income, and the differences attributable to non-qualified employee stock options. He finds that these items cannot fully explain the difference and argues that the residual difference is likely due to tax shelter activity.

While not the focus of this paper, the book-tax difference created by non-qualified stock options (NQOs) warrants some attention because several researchers have singled out this item as a potential driving factor in the increasing book-tax gap (e.g., Yin, 2001; Desai, 2003). ${ }^{22}$ For financial accounting purposes, an expense for stock option compensation was not required in any of the years analyzed in the above mentioned studies. The accounting rules in place during those years encourage firms to recognize as compensation expense the fair value (i.e., the estimated value determined from an option pricing model such as the Black-Scholes model or the binomial option pricing model) of employee stock options (ESOs) at the measurement date (the date on which both the exercise price and number of options are known), but allows firms to continue accounting for ESOs by expensing the intrinsic value on the day of grant (zero for most firms). ${ }^{23,24}$

In contrast to financial accounting, for tax purposes, NQOs entitle the granting firm to a deduction equal to the amount of ordinary income recognized by the employee on the exercise date. ${ }^{25}$ Thus, the ESO tax deduction equals the intrinsic value (market price less the strike price) at exercise.

As a result, for NQOs, most firms obtain a tax deduction in the exercise year but never recognize compensation expense for financial reporting purposes. Thus, a difference exists between book and taxable income. ${ }^{26}$ This book-tax difference is not obvious on financial statements, however, because the rules require that the tax benefits related to NQOs be accounted for as a credit to additional paid-in capital with an offsetting debit to income taxes payable (thus, no reduction to tax expense). ${ }^{27}$ Yin (2001) and Desai (2003) continue to find an increas- 
ing book-tax gap even after excluding this potentially large book-tax difference (as do we).

The accounting for stock options is a fruitful example of how Congress will likely get involved if book and tax incomes are conformed in the United States. The question of whether to expense stock options has been a politically controversial issue for years, with Congress getting involved with the rulemaking for financial reporting purposes. For example, in 1993, Senator Feinstein of California introduced a bill to block the FASB's plan to require expensing of the fair value of stock option grants. In 1994, Senator Lieberman of Connecticut introduced legislation that would have eliminated the FASB's independence by requiring the SEC to approve all new FASB standards. The FASB responded by not requiring firms to expense stock options. This is an ongoing issue. As the FASB attempts to respond to the recent accounting scandals and the International Accounting Standards Board's stance that stock option grants are compensation and should be expensed, they are again met with opposition from Congress. In 2004, a bill was passed in the House of Representatives (House Bill H.R. 3574, the Stock Option Accounting Reform Act) that essentially requires firms to ignore any new FASB standard requiring the expensing of stock options for other than the top five executives of the firm. With this level of involvement in financial accounting rulemaking under a dual reporting system, it is likely that Congress will not concede the rulemaking for their revenue to an independent board and will have direct, and probably total, control over the rulemaking under a conformed income system. In section 5.2.1, we discuss the experience in this regard of other countries that have more closely aligned book and taxable incomes.

In sum, there is evidence of a growing gap between book income and taxable income; however, there is little compelling evidence on precisely what is causing this divergence. Most speculate that it is either firms generally managing their earnings upward or using tax shelters to manage their taxable income downward. As a result, the proposed fixes to the problem of the growing gap generally seek to address both issues. We examine the proposed fixes next.

\section{Proposed Fixes to the Current System}

There have been three main proposed fixes to the problem of the diverging incomes. First is the disclosure of the entire corporate tax 
return. For example, on July 8, 2002, Senator Charles Grassley of Iowa, then ranking member of the Senate Finance Committee, wrote a letter to the SEC and the Treasury Department raising the question of whether government regulators and the public might benefit if corporate tax returns were made public. He asked whether corporate governance would be improved if corporations' tax returns were available to the SEC and whether shareholders and employees would benefit if tax returns were publicly available. ${ }^{28}$ Second is the disclosure of limited tax return information such as the amount of taxable income. In April 2003, Representative Lloyd Doggett of Texas introduced a bill that provided for public disclosure of certain corporate tax return information such as corporate taxable income and income tax shown on the return, the amount of federal income tax expense on the company's annual report, the company's adjusted book income, and certain items causing the discrepancy between tax and book income.

A thorough discussion of these first two options, publicly disclosing tax returns and publicly disclosing limited tax information, is provided by LSS and the interested reader is directed there. In sum, the authors in their (tentative) conclusions support the second of these proposals (i.e., the disclosure of total tax liability and other specific items from the tax return) but do not support the disclosure of entire tax returns. They argue against the first proposal because of their concern that the disclosure of the entire tax return could cause companies to dilute the information content of the returns, hampering tax enforcement, and might, even in diluted form, reveal proprietary information that could provide a competitive advantage to companies that are not required to make such a disclosure. They support the revelation of taxable income and other items, however, because this would "contribute to the transparency of the tax system by clarifying the tax payments of corporations in and of themselves, relative to other corporations, and relative to the income they report on their financial statements" (p. 827).

The third proposed solution is to conform the two incomes into one measure or have partial conformity by reducing the number of allowable book-tax differences. In addition to the calls for conformity by Yin (2001) and Desai (2004), the Treasury in its report suggests using "book income as a floor on the corporation's taxable income. This would eliminate the book-tax disparity, and therefore would significantly limit the allure and benefit of corporate tax shelters to public corporations" (p. 116). In addition, Murray writes in the Wall Street Journal, "The gap can and should be narrowed... The results would be a 
stronger incentive for companies to tell it like it is. If executives want to overstate income to fool shareholders, they'll pay higher taxes as a result. If they are tempted to understate income in order to escape taxes, they'll suffer with the shareholders. That kind of change in incentives would do far more to clean up corporate accounting than any amount of regulatory oversight" (Murray, 2002). Finally, Pam Olson, the former treasury assistant secretary for tax policy, states, "[W]e should also carefully consider eliminating some of the differences between book and tax reporting" (Hamilton and Radziejewska, 2003, p. 1935). We now turn to this issue.

\section{Issues with Conformity}

When considering conforming book and taxable incomes, one first must ponder how this would actually work. What income measure would be reported if the numbers are conformed? Would the new measure be the taxable income we have under the current system, or the financial accounting number, or some hybrid number in between? In addition, who would govern the rulemaking for this new conformed income measure-Congress directly or an independent board such as the FASB under today's structure?

Our conjecture is that the new measure would approximate today's taxable income number, and rulemaking responsibility would be under the direction of Congress. If the conformed number is the one on which tax revenues will be based, we do not believe Congress will leave its determination up to an independent board unconcerned with the Treasury's budgetary needs. Partial conformity, where both measures are retained but the differences between the two are significantly reduced, is also an option. ${ }^{29}$ However, in light of George Stigler's (1971) work, where he discusses how regulators are often captured by the regulated enterprises, promoting the interests of the firms instead of the common good, we doubt a reduction in the differences would be successful (again, note the stock option controversy where the constituents of Congress have been very influential). Further, Hulse (1996) finds that often special tax treatment is included in legislation to obtain the vote of particular legislators and that $\$ 10.6$ billion of such provisions were included in the Tax Reform Act of 1986. Thus, a reduction of the book-tax differences is unlikely, at least in the long run, because differences would continually be added to satisfy special interest groups and constituencies. As a result, we discuss the costs 
and benefits of the proposal to conform the incomes, with the underlying assumption that if the two incomes are conformed, the reported measure of income will be, or at least approach, the current measure of taxable income, and the rulemaking will be done directly by Congress rather than an independent, private board. ${ }^{30}$

Before we examine the costs and benefits of conformity, we first note that this is not an entirely new concept. The Tax Reform Act of 1986 required a book income adjustment in the calculation of a firm's alternative minimum tax (AMT). This was the first time in U.S. tax history that a federal income tax liability was based partially on income derived explicitly from financial statements prepared in accordance with GAAP. The link was established to "ensure that no taxpayer with substantial economic income can avoid significant tax liability by using exclusions, deductions, and credits" [S. Rep. No. 99-313, at 518 (1986)]. However, many speculated that firms would manage their financial accounting earnings in the years surrounding the change in the tax provisions in order to minimize their tax liabilities in those years. Further, some thought that the link weakened financial accounting. For example, acting Assistant Treasury Secretary for Tax Policy John Wilkens stated:

The book income adjustment may be having a detrimental effect on the quality of financial reporting. The linkage between financial statement income and tax liability creates an incentive for corporations potentially subject to the AMT to apply generally accepted accounting principles (GAAP) in a way that reduces the amount of net book income subject to the book income adjustment. Accordingly, general purpose financial statements may provide distorted financial data to investors, creditors, and other nontax users ... (U.S. Congress, House, June 8, 1989).

However, the empirical evidence on this question of whether firms managed financial accounting earnings in order to minimize their tax liabilities is mixed, with some studies finding that firms did manage financial accounting earnings in order to reduce taxes (e.g., Gramlich, 1991; Dhaliwal and Wang, 1992) but with Choi et al. (1998) concluding that little evidence supports the AMT-driven income shifting.

\subsection{Potential Benefits of Conforming Book and Taxable Incomes}

Many argue that the temptation on the part of executives to mislead/ lie for either financial accounting or taxable income purposes would be significantly reduced or even eliminated (Yin, 2001; Desai, 2004; 
Carnahan and Novack, 2002). Executives would not be inclined to overstate income because this would result in higher taxes, and they would not want to understate income because this would result in lower income reported to creditors and shareholders. In addition, many argue it would simplify a currently very complex reporting environment.

A second potentially important benefit of conforming the income measures is that corporations would incur less compliance cost because they would report (essentially) the same measure to both the IRS and the SEC. As an example of the magnitude of the costs incurred currently under the dual reporting system, in 2003, the total revenues for the four largest accounting firms for auditing and advisory services was $\$ 9.6$ billion, and total revenues for tax services for these firms was $\$ 5.5$ billion. ${ }^{31}$ Together, this is approximately 3 percent of the total reported earnings of the firms in the S\&P 500 index. ${ }^{32}$ Another example of the costs is found in Slemrod and Blumenthal (1996). The authors survey 1,329 of the largest corporations in the United States in 1992 and find the average annual cost of compliance for federal and subfederal corporate income tax reporting is $\$ 1.565$ million, implying an aggregate compliance cost of over $\$ 2$ billion.

\subsection{Potential Costs of Conforming Book and Taxable Incomes}

There are potential costs to conforming the incomes as well. Most notable is the loss of information to the financial markets. There is a long line of literature in the United States demonstrating the value relevance and information content of financial accounting earnings and earnings announcements, beginning with Beaver (1968) and Ball and Brown (1968). ${ }^{33}$ Thus, if our conjecture is correct and taxable income is the income measure that is used after the two incomes are conformed, financial accounting earnings will no longer be available, resulting in a loss of information to the capital markets. More specifically, the loss of information would occur because, as LSS discuss, many accruals that financial accountants use to reflect current economic performance would be eliminated if the incomes are conformed. One example is bad debt expense. As discussed above, under GAAP, this expense is estimated and matched to the associated revenues, while for tax purposes the deduction is not taken until the account receivable actually is known to be uncollectible. If this book-tax difference is removed and the tax treatment prevails, then profits and assets will be overstated in the period of the sale because one of the costs of generating the sale 
will not be properly matched to the revenue. Thus, this year's profit will appear high, while future periods will have to absorb the related expenses.

\subsubsection{Value Relevance of Financial Accounting Earnings in Interna-} tional Settings As discussed above, prior research has established that financial accounting earnings in the United States are value relevant. Several recent studies investigate the value relevance of accounting earnings across countries, including countries that have a high level of association between financial accounting and tax incomes. This research provides indirect but important evidence on the potential loss of information if the United States would conform book and tax incomes to one measure.

The closest study providing information on the issue is by Ali and Hwang (2000), who examine the relation between measures of the value relevance of financial accounting data and several countryspecific factors. Value relevance is defined as the relevance (importance) of accounting earnings to investors in the pricing of stocks (we discuss empirical operationalization of the concept in section 5.2.2 below). The country-specific factors examined by Ali and Hwang (2000) include the degree to which tax rules influence financial accounting measurements, the involvement of a private-sector body in the standard-setting process, and whether the country has a bankoriented or market-oriented financial system. Ali and Hwang (2000) find that value relevance of earnings is lower when tax rules significantly influence financial accounting measurements. This result is consistent with tax laws being influenced by political, social, and economic objectives rather than the information needs of investors. This evidence would lead to the prediction that if book and tax incomes are conformed in the United States, there would be a loss of value-relevant information in the capital markets.

The authors also find that value relevance of financial accounting earnings is lower for countries where private-sector bodies are not involved in the standard-setting process. This finding is consistent with the premise that government standard setters establish financial accounting rules with the primary purpose of satisfying regulatory needs rather than providing performance information to investors. Thus, if under a conformed income regime, the FASB is eliminated and the government promulgates the rules for the conformed income measure, a loss of information to the market would result. 
Ali and Hwang (2000) also find that financial accounting data are less value-relevant when the financial system is more bank-oriented as compared to market-oriented. This result is consistent with a lower demand for published value-relevant financial reports because the banks have direct access to the financial information of the company. This is important to the proposal to conform incomes in the United States because under the condition where financial accounting income is not the conformed income measure, as we conjecture, it is likely that information regarding performance will be obtained by interested parties through other methods. Indeed, Ball, Kothari, and Robin (2000) report that investors in countries that are more code oriented (i.e., where tax and book incomes are very closely linked) use other means (such as banking relationships and relationships with other major stakeholders) to obtain information about firm performance. Ball, Kothari, and Robin (2000) also find that valuation in these countries is much less related to reported earnings, consistent with the findings of Ali and Hwang (2000). ${ }^{34}$

In addition to the value-relevance effects of linking tax and book incomes, studies also point to the more conservative nature of earnings when book and tax incomes are closely linked. For example, Joos and Lang (1994), in their study of the effects of accounting diversity across the European Union, state that in those countries where the link is strong, "the required conformity between financial and tax reporting has provided incentives to reduce taxes by reporting lower profits" (p. 145). ${ }^{35}$ Thus, linking the two incomes may indeed reduce the overstating of earnings for financial accounting. Based on the evidence in the research discussed above, however, the income number we would be left with would not be as useful for evaluating firm performance.

\subsubsection{A Comparison of the Value Relevance of Book and Tax}

Incomes While there is an extensive literature on the value relevance of accounting earnings in the United States and several papers about the value relevance of accounting earnings across countries, there is little research examining the value relevance (or informational) role of taxable income. One recent paper that does is by Hanlon, Kelley, and Shevlin (2005; HKS), who examine whether and to what extent information to stock market participants would be lost if financial accounting income is conformed to taxable income.

The study uses a sample of 66,678 U.S. firm-year observations over the period 1983-2001 to conduct tests to assess the information content 
of book and estimated taxable incomes. Information content is measured by the ability of income to capture or summarize information that affects equity prices and returns. HKS use information from firms' financial statements to estimate taxable income because taxable income is not publicly available. While there are some known estimation errors associated with using financial statements to estimate taxable income, for the purposes of their tests, the financial statement number is more appropriate than the actual taxable income from tax return data (if such data were obtainable) because the market can only use the publicly available measure in pricing securities. ${ }^{36}$ Specifically, the authors estimate (world-wide) taxable income by summing federal and foreign current income tax expense and dividing this by the top statutory tax rate for the applicable year. The authors then subtract the change in net operating loss carryforwards because they want the estimate of taxable income prior to the effects of any carryforwards of net operating losses. The study uses a 16-month long event window to calculate market-adjusted security returns and tests the association of these returns with both book (world-wide pre-tax financial accounting income) and estimated taxable incomes. More specifically, the return is the market-adjusted return for each firm, defined as the compound (with dividend) return less the compound return on the valueweighted market portfolio. Returns are calculated over a 16-month period, starting at the beginning of the fiscal year and ending four months after the end of the fiscal year so that all of the financial statement information is available to market participants.

The authors assess the relative information content of the income measures by regressing the buy-and-hold market-adjusted return to the security over the 16-month return window on the change in each annual measure of income. The regression models are as follows:

$R_{j t}=a_{0}+a_{1} \Delta \mathrm{PTBI}_{j t}+e_{j t}$

$R_{j t}=b_{0}+b_{1} \Delta \mathrm{TI}_{j t}+e_{j t}$

where $R_{j t}$ is the buy-and-hold market-adjusted return to each security, $j$, over the 16-month return window; ${ }^{37}$ PTBI is pre-tax book income; and TI is estimated taxable income. Each model is estimated annually. A comparison of the annual $R$ squareds allows the determination of which measure of performance, book income or taxable income, is more highly associated with stock returns in each year. The average annual $R$ squared for the regression using the change in (pre-tax) book 


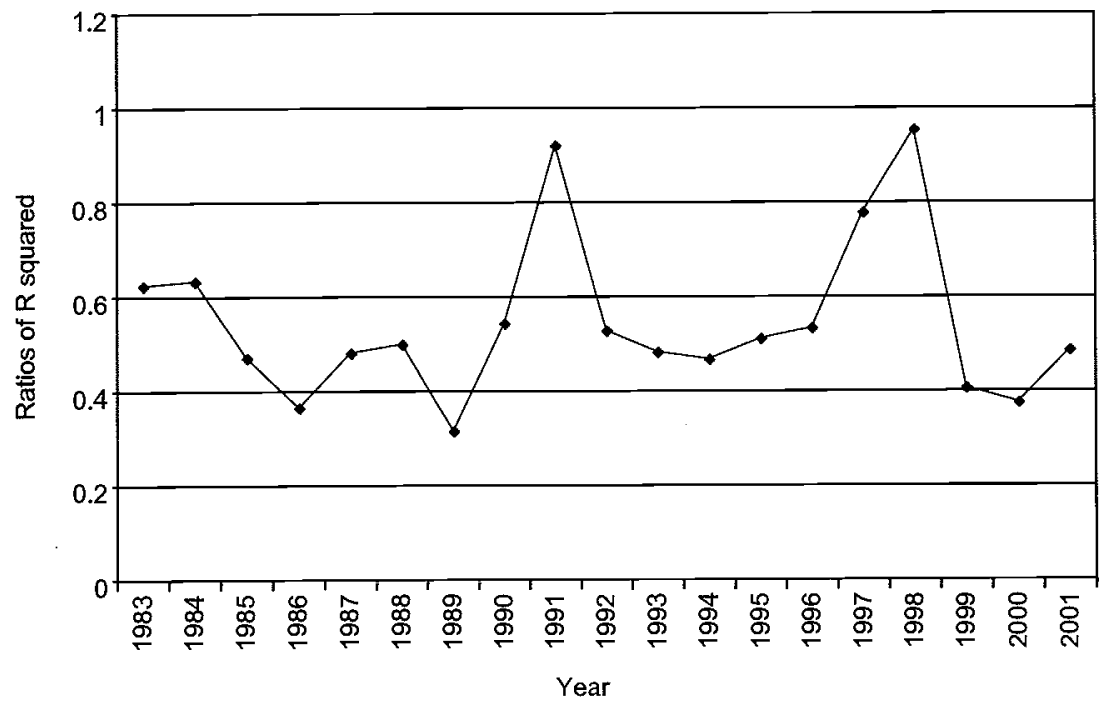

Figure 5

Plot of the Ratios of $R$ Squared from Tests of Relative Information Content from Hanlon, Kelley, and Shevlin (2005)

The ratio comprises the $R$ squared from the following two regressions: $R_{j t}=a_{0}+$ $a_{1} \Delta \mathrm{PTBI}_{j t}+e_{j t}$ and $R_{j t}=b_{0}+b_{1} \Delta \mathrm{TI}_{j t}+e_{j t}$, where $R_{j t}=$ the market-adjusted buy-and-hold return on security $j$ cumulated over a 16-month window ending 4 months following the end of the fiscal year $t$; $\triangle P B T I=$ the change in firm $j$ 's pre-tax book income, which is calculated as the first difference in pre-tax book income less minority interest, scaled by the market value of equity at the beginning of period $t ; \Delta \mathrm{TI}=$ the change in firm $j$ 's taxable income, which is estimated by dividing the sum of federal and foreign tax expense by the maximum statutory tax rate, subtracting the $\Delta \mathrm{NOL}$ carryforward, and then taking the first difference. If this information is not available, $\Delta \mathrm{TI}$ is calculated by dividing the difference of current tax expense and deferred taxes by the maximum statutory tax rate, subtracting $\triangle N O L$ carryforward, and then taking the first difference. Finally, the result is scaled by the market value of equity at the beginning of period $t$. The adjusted $R^{2}$ ratio $=R_{\Delta \mathrm{TI}}^{2} / R_{\Delta \mathrm{PTBI}}^{2}$.

income is 0.059 , while the average annual $R$ squared for the regression using the change in estimated taxable income is only 0.032 . Figure 5 plots the ratio of $R$ squareds from HKS's analysis. One can see that the ratio varies around 50 percent for most of the years, indicating that pre-tax book income exhibits higher explanatory ability (roughly twice as much in most years). A formal comparison of the adjusted $R$ squareds from the annual regressions is conducted using the Voung (1989) test. The results of the Voung test indicate that in all but three years of the sample period 1983-2001, book income exhibits significantly greater explanatory power than estimated taxable income. 
Further, the average annual $R^{2}$ ratio is 0.547 , which is significantly less than one based on its time-series variation. In sum, the results of this test are consistent with book income containing more information because it has a significantly higher explanatory power than estimated taxable income.

HKS also conduct a test of incremental information content, where changes in both measures of income are included in the same regression in which the dependent variable is the 16-month market-adjusted security return. The estimated regression model is as follows:

$R_{j t}=c_{0}+c_{1} \Delta \mathrm{PTBI}_{j t}+c_{2} \Delta \mathrm{TI}_{j t}+e_{j t}$

From this test, an assessment can be made whether, given one measure of income, the other measure incrementally adds to the information set as reflected in security returns. This analysis tests most directly whether useful information would be lost if the two income measures become one. We present a summary of their results in Table 2. The authors find that book income has a significantly positive average annual coefficient $\left(c_{1}=0.55, t\right.$-statistic of 18.87) as does estimated taxable income ( $c_{2}=0.28, t$-statistic of 7.65$)$. Thus, both measures provide information incremental to the information provided by the other measure, which indicates that there would be a loss of information available to investors if only one of these two income measures were used.

In sum, the study shows that both book and tax measures of income provide information to investors but that the market appears to rely more on book income than taxable income as a measure of firm performance. The authors conclude from the study that if book income were conformed to taxable income, there would be an approximately 50 percent loss in the explanatory power of earnings.

\subsubsection{Potential Effects of Having Taxable Income Available to the} Public If our conjecture is correct that conformed income would resemble taxable income, there will likely be additional effects simply from having taxable income publicly disclosed. On one hand, public disclosure of taxable income may facilitate greater tax compliance because company executives may be concerned that if it is known that their taxable income is unusually low, the public may react adversely. Indeed, as LSS report, corporations' concern with their public image is evidenced by their charitable giving of $\$ 9.05$ billion in 2001. In addition, the public may boycott the products of companies thought to be poor corporate citizens (e.g., the Nike sweatshop controversy). Further, 
Table 2

Portion of Table 4 from Hanlon, Kelley, and Shevlin (2005): Incremental Information Content, $R_{j t}=c_{0}+c_{1} \Delta \mathrm{PTBI}_{j t}+c_{2} \Delta \mathrm{TI}_{j t}+e_{j t}$

\begin{tabular}{llll}
\hline Year & $\mathrm{N}$ & $\Delta \mathrm{PTBI}$ & $\Delta \mathrm{TI}$ \\
\hline 1983 & 2,225 & $0.67^{*}$ & $0.50^{*}$ \\
1984 & 2,866 & $0.41^{*}$ & $0.23^{*}$ \\
1985 & 2,984 & $0.54^{*}$ & 0.12 \\
1986 & 2,933 & $0.59^{*}$ & 0.08 \\
1987 & 3,048 & $0.43^{*}$ & $0.16^{*}$ \\
1988 & 3,188 & $0.48^{*}$ & $0.19^{*}$ \\
1989 & 3,182 & $0.50^{*}$ & 0.03 \\
1990 & 3,140 & $0.43^{*}$ & $0.13^{*}$ \\
1991 & 3,180 & $0.43^{*}$ & $0.39^{*}$ \\
1992 & 3,238 & $0.61^{*}$ & $0.21^{*}$ \\
1993 & 3,454 & $0.64^{*}$ & $0.32^{*}$ \\
1994 & 3,741 & $0.60^{*}$ & $0.26^{*}$ \\
1995 & 3,999 & $0.83^{*}$ & $0.57^{*}$ \\
1996 & 4,233 & $0.59^{*}$ & $0.38^{*}$ \\
1997 & 4,544 & $0.62^{*}$ & $0.59^{*}$ \\
1998 & 4,449 & $0.34^{*}$ & $0.44^{*}$ \\
1999 & 4,258 & $0.53^{*}$ & $0.23^{*}$ \\
2000 & 4,077 & $0.79^{*}$ & $0.29^{*}$ \\
2001 & 3,939 & $0.47^{*}$ & $0.27^{*}$ \\
Average & & 0.55 & 0.28 \\
$t$-statistic & & 18.87 & 7.65 \\
\hline
\end{tabular}

$R_{j t}=$ the market-adjusted buy-and-hold return on security $j$ cumulated over a 16-month window ending 4 months following the end of fiscal year $t . \triangle \mathrm{PBTI}=$ the change in firm $j$ 's pre-tax book income, which is calculated as the first difference in pre-tax book income less minority interest, scaled by the market value of equity at the beginning of period $t$. $\Delta \mathrm{TI}=$ the change in firm $j^{\prime}$ s taxable income, which is estimated by dividing the sum of federal and foreign tax expense by the maximum statutory tax rate, subtracting the $\triangle N O L$ carryforward, and then taking the first difference. If this information is not available, $\Delta \mathrm{TI}$ is calculated by dividing the difference of current tax expense and deferred taxes by the maximum statutory tax rate, subtracting $\Delta \mathrm{NOL}$ carryforward, and then taking the first difference. Finally, the result is scaled by the market value of equity at the beginning of period $t . N$ is the number of observations used in estimating each annual regression. The $t$ statistic is based on the annual deviation of the coefficient around its grand mean.

* Significance at the 0.05 level or lower. 
according to a survey of 2,594 adult Americans by Hill and Knowlton (2001), 79 percent of Americans said that they consider good corporate citizenship when deciding whether to buy a particular company's stock.

On the other hand, the revelation of corporate taxes may result in corporate competition based on taxes, leading to a "race to the bottom" of tax rates (LSS). Already, websites such as CFO.com allow chief financial officers to measure their company's performance against peers on four dimensions, one of which is tax efficiency (Desai, 2004). Further evidence that suggests firms compete on this measure and use low taxes as a source of corporate profits is a recent GAO report, which finds that 32.7 percent of large U.S. corporations reported no tax liability in 1995, and that percentage increased to 45.3 percent by 2000 (GAO, 2004).

Thus, while many argue that conforming the two income measures will yield more honest reporting for both book and tax purposes, this outcome is not clear. Firms may just compete based on tax rates to pay low taxes, yielding higher cash flows for shareholders. If this is the case, corporate overreporting on financial statements will not be such an issue, but investors will instead have very little information on which to evaluate firm performance.

\subsection{Partial Conformity}

There is also the possibility that rather than fully conforming the two income numbers, the number of book-tax differences allowed could be reduced. While this sounds reasonable on paper, in practice, which differences would be disallowed? We stated above that we think that before long, with a reduced book-tax difference system, we would be back to the current system with innumerable adjustments because the private interest groups and constituencies that lawmakers serve will demand special exceptions for their specific situations. ${ }^{38}$ In this section, however, we briefly examine some items that could potentially be conformed.

The most obvious book-tax difference that could be conformed is that for depreciation. Financial accounting could adopt the tax method of depreciation, MACRS. This would result in many firms switching from straight-line depreciation to accelerated depreciation. It is unlikely that this would result in a loss of information to investors because economic depreciation of an asset does not follow either of these methods exactly. In addition, the expected life of the asset could still be 
disclosed to investors. ${ }^{39}$ Thus, this is one difference that could be eliminated with minimal cost in terms of revenue or information. ${ }^{40}$

Another item one could consider is deferred revenue. For financial accounting purposes, an item of revenue is not recognized (i.e., it is deferred) if it is not earned or is not measurable. Thus, when software companies sell software with a service contract over a number of years, the revenue allocable to the service contract is not recognized in income until the service period expires. For tax purposes, however, this revenue is taxed upon receipt. If the deferral method were adopted under both systems, there would be a deferral of revenue for tax purposes, resulting in a loss of government revenues (at a minimum in terms of present value) and measurement for tax done by subjective estimates. If the recognition upon receipt method were adopted under both systems, investors would be left without information regarding a liability of the firm (i.e., the services yet to be performed), and a firm could report revenues currently that are related to expenses that will not be incurred for several years, thus potentially misleading financial statement readers about firm performance.

Another example is the allowance for doubtful accounts. If conformed to the tax method of allowing only specific write-offs, investors will not receive information from managers regarding the proportion of the current receivables that are expected to be uncollectible. However, if tax were to conform to the financial accounting method of estimating the amount to expense, the government would again suffer a revenue loss and be subject to deductions based on management expectations, which would be impossible to verify and audit.

While the examples are endless, in general, most items present a trade-off between information for investors and revenue and control for the government. For some items (such as depreciation), the loss of information may not be large if financial accounting converted to the tax method, and other items (e.g., debt-equity hybrid securities and synthetic leases) could arguably be conformed while still providing information to external stakeholders, but the majority of book-tax differences would likely involve the aforementioned trade-off. Another item that warrants attention is the suggestion to eliminate many book-tax differences and then require firms to provide details in the notes to financial statements with additional information. However, there is a point at which a high level of disclosure becomes non-disclosure because time and funds are not infinite for investors (even sophisticated investors) to assimilate that much information. In addition, we note 
again that perhaps the greatest concern about the partial conformity plan is that we would soon be back to the current system because special interest groups and constituencies would lobby Congress to retain book-tax differences important to them and these would be added continually through the years.

\section{Conclusions}

This paper discusses the issues surrounding the proposals to conform financial accounting income and taxable income. We review recent literature that sheds light on this proposal in order to inform the policy debate regarding what to do about the current reporting gap between financial accounting and taxable incomes.

The expanding divergence between book and taxable incomes has attracted much attention and analysis in recent years. While there is little debate that the incomes are diverging, what is causing the divergence and whether and how to fix it are very much open questions. In general, there is no convincing evidence regarding exactly what is causing the increasing book-tax gap. However, most suspect that it is due to firms managing financial accounting earnings upward, engaging in tax shelters in order to minimize taxable income, or both. There have been three proposed solutions to the problem of the increasing divergence between the two incomes. We discuss the third proposal, the conforming of book and taxable incomes to one measure.

We conjecture that upon conforming the incomes, Congress will usurp FASB and will promulgate the rules for determining the new income measure. In light of this, we consider both the potential costs and benefits of changing our dual reporting system to one in which corporations report the same income to shareholders and the IRS. Potential benefits include lower compliance cost for reporting their income and the potential lowering of incentives to mislead the IRS and capital markets. The potential costs include the loss of value-relevant information to the capital markets by eliminating one measure of income, with the greater loss coming from eliminating financial accounting earnings. In addition, the extant empirical literature reveals that it is unlikely that having a system where financial accounting earnings and taxable income are conformed (or even closely linked) will result in a reduction of corporate tax shelters. In fact, the opposite may occur, where there is a "race to the bottom" in terms of corporate tax rates and payments. 


\section{Notes}

We appreciate helpful comments from Ed Maydew, Jim Poterba, Doug Shackelford, Doug Skinner, and Joel Slemrod.

1. Mills (1998) finds that the larger the level of book-tax differences, the greater the Internal Revenue Service (IRS) audit proposals and adjustunents. Lev and Nissim (2004) and Hanlon (2005) both provide evidence that large book-tax differences are associated with lower quality of financial accounting earnings. Thus, there is evidence that book-tax differences can indicate both aggressive tax behavior and aggressive financial accounting reporting.

2. There is also a fourth possible solution: increase the disclosures required under Financial Accounting Standard 109, Accounting for Income Taxes, to provide better information about the book-tax differences of the firm and the firm's actual tax liability. We do not discuss this solution further, but the interested reader is referred to Hanlon (2003) for more details.

3. One way to accomplish such disclosure would be to require public disclosure of the new Schedule M-3. The M-3 is a more detailed (than the Schedule M-1) reconciliation of book to taxable income effective for any taxable year ending on or after December 31, 2004, and must be filed by any corporation required to file Form 1120, U.S. Corporation Income Tax Return, that reports on Form 1120 at the end of the corporation's taxable year total assets that equal or exceed $\$ 10$ million. The new Schedule M-3 is designed to increase transparency for IRS agents and make tax reporting requirements more uniform. Currently, this new schedule is confidential and not publicly available; thus, it will not help financial statement users.

4. LSS state that the proprietary information that may be disclosed through tax returns includes the nature, sources, and character of a company's revenues and expenses; details about a company's legal structures, licensing, and leasing revenues by legal entity and jurisdiction; advertising and other selling expenses; and the nature and location of a company's manufacturing costs by functional type (p. 823).

5. We recognize that various proposals to overhaul the income tax system entirely (e.g., a consumption tax) would render the proposal of conforming book and tax incomes meaningless because, with a consumption tax, there will no longer be a taxable income with which to compare financial accounting earnings.

6. Regarding these cases, Representative Lloyd Doggett stated that "when investors hear of only rosy earnings while at tax time Uncle Sam only hears of regrets and red ink, something is very wrong" (Weisman, 2002, p. A01).

7. Firms could voluntarily continue to disclose information about their earnings performance similar to current financial accounting income. While this is true, the information that would be disclosed would not be computed under a common set of rules and the firms could voluntarily disclose different information (or pieces of information) to different parties at different times. This type of reporting would invariably result in less reliable and less comparable information, and to an information disadvantage to certain groups of investors (most likely small investors). The disadvantaged investors will either (a) leave the market or (b) demand a higher return for the now higher risk of investing. This will in turn make equity more expensive because of a greater amount of information asymmetry and lower amount of liquidity. 
8. We discuss evidence from international settings with regard to this point below; the reader can find U.S. evidence in Guenther et al. (1997).

9. For a very readable and extensive discussion on the differences between taxable income and book income, see Knott and Rosenfeld (2003).

10. Technically, the term permanent difference is not used in Statement of Financial Accounting Standard No. 109 (SFAS 109). However, permanent-type differences continue to affect the calculation of current tax expense under SFAS 109 (KPMG Peat Marwick, 1992).

\section{IRC Section 446 (b).}

12. See Mills and Plesko (2003) and Boynton and Mills (2004) for more information surrounding the new Schedule M-3. In addition, any book-tax difference greater than $\$ 10$ million must be disclosed separately to the IRS under Treasury regulation $\$ 1.6011-4 \mathrm{~T}$.

13. There have been some proposals that include making the M-3 public. The M-3 data will be unavailable to the public (except possibly for a few specific agreements with a handful of academic researchers).

14. See also McGill and Outlsay (2002 and 2004), who examine some of the recent tax shelter cases to show that financial statement disclosures are limited with regard to information about a firm's tax status.

15. For example, Desai (2004) uses anecdotal evidence from major corporate scandals (Enron, Tyco, and Xerox) to show that managers exploit the differences between book and tax reporting opportunistically, thereby reducing the quality of corporate earnings measures for both book and tax purposes.

16. The data for the GAO study are from the IRS's Statistics of Income (SOI) samples of corporate tax returns for tax years 1996-2000.

17. Note that our estimated taxable income is based on financial statement information and thus is subject to considerable measurement error. This should be considered when evaluating the results - these are only estimated figures for taxable income.

18. Our pre-tax book income is derived by deducting minority interest (Compustat data item 49) from pre-tax book income (data 170). Note that pre-tax book income (and estimated taxable income) includes the effects of special items (which the effects of the $9 / 11$ attacks are likely classified as) but excludes the effects of extraordinary items and discontinued operations. In the calculation of estimated taxable income, we subtract the change in the year-end net operating loss (NOL) carryforward because we require an estimate of the firm's taxable income (or loss) for the year prior to the effects of any carryback or carryforward.

19. Our measure of the difference between book and taxable income does not include the book-tax difference for non-qualified stock options, discussed more fully below.

20. To obtain further information on these special items, we hand-collect the financial statements for 10 firms in the year 2001 from the HKS sample that have a large negative difference between book and taxable incomes (i.e., taxable income is greater than financial accounting income). We find that the majority of the negative special items for these firms are the following (or a combination of the following): (1) write down for the impairment of goodwill and other intangible assets, (2) restructuring charges, and (3) the writeoff of acquired in-process research and development. 
21. Manzon and Plesko's (2002) model includes sales growth, property, post-retirement benefits, foreign pre-tax income, lagged book-tax differences, and others.

22. A non-qualified employee stock option is one of two types of employee stock option (ESO). The other type is an incentive stock option (ISO), or qualified option. An ISO is an option that qualifies for treatment under IRC sections 421-424. Non-qualified options constitute the vast majority of stock option grants. Much of this discussion about the stock option treatment is from our earlier work: Hanlon and Shevlin (2002) and Hanlon (2003).

23. The rules are found in Statement of Financial Accounting Standards No. 123, Accounting for Stock Based Compensation, and the rules prior to that are found in Accounting Principles Board No. 25, Accounting for Stock Issued to Employees. The FASB has proposed rules, which are currently slated to be effective for financial statements beginning after June 15, 2005, that require the expensing of stock option compensation.

24. Prior to the recent surge in firms electing to expense their option costs, there were only two firms in the Fortune 500 that recognized compensation expense related to ESOs: Boeing and Winn Dixie. Since the recent accounting scandals, however, many firms, such as Coca-Cola, Wal-Mart, Ford Motor Company, Home Depot, Bank One, and others, have elected to account for their stock options using the fair value method.

25. This deduction is listed in Internal Revenue Code $\$ 83(\mathrm{~h})$ as a deductible expense, as defined in $\$ 162$.

26. See our earlier work, Hanlon and Shevlin (2002), for additional discussion on the accounting treatment of the tax benefits of stock options. It is important to note that even if firms elect or are required to expense stock options for financial accounting purposes, there is still a difference in the timing and amount for book versus tax treatment.

27. The board's reasoning was that the tax benefits are related to a capital transaction with the owners of the company rather than a transaction related to income (see Accounting Principles Board No. 25, para. 17).

28. We note that the SEC can gain access to tax returns because IRC $\$ 6103(i)(3)$ permits the IRS to disclose certain otherwise confidential tax information to other federal agencies if the information may constitute evidence of a violation of any federal criminal law.

29. We discuss this option further below.

30. We admit that the FASB has also succumbed to political pressure in the past regarding the accounting for marketable securities, employee stock options, and business combinations. However, we argue that Congress exerted much of this pressure. See Zeff (2002) for a discussion of each of these three issues and the politics involved.

\section{From Public Accounting Report's Top 100.}

32. Reported earnings for the S\&P 500 for the four quarters in 2003 was $\$ 450.38$ billion (see Standard and Poor's S\&P 500 Earnings and Estimate Report at www standardandpoors.com). We note that in some sense this is a lower bound estimate of the costs that firms incur because these figures are only for the largest four accounting firms and do not include the in-house and other costs required to comply with the IRS regulations and FASB and SEC standards. On the other hand, this calculation may overstate the compliance costs of two systems because it includes foreign and state-related amounts as well as audit (i.e., checking the books, the internal controls, etc.) costs that presumably occur under either system. 
33. See Kothari (2001) for an extensive review of the literature examining the capital market's use of accounting information. In addition, there have been several studies examining the information content of financial accounting earnings over time using short-window event study methodology. All of these short-window studies find results consistent with the information content of earnings remaining constant or slightly increasing over time (e.g., Landsman and Maydew, 2002; Lo and Lys, 2000). There have been some long-window studies showing that the value relevance of accounting earnings has decreased over time (e.g., Collins, Maydew, and Weiss, 1997; Brown, Lo, and Lys, 1999; Francis and Schipper, 1999). One explanation is that there is an increasing number of firms reporting losses. For example, Joos and Plesko (2005) report that in the 1970s, only 15 percent of the Standard and Poor's Compustat database reported a loss, but by the $1990 \mathrm{~s}$, about 35 percent of the observations are losses. In addition, Skinner (2004) discusses changes in reported earnings over the last 25 years and argues that recent research documents that there has been a large increase in the frequency and magnitude of losses (in 2001, aggregate earnings were a negative $\$ 110$ billion, with 59 percent of firms reporting losses). Further, Fama and French (2004) find that after 1979, the characteristics of new listings change. For example, they argue that weaker firms with more distant expected payoffs became more viable candidates for public financing in the last 25 years. This increase in loss firms is important because losses are known to be less informative about a firm's future prospects (and thus less related to a firm's value) than are profits (Hayn, 1995). However, conforming the incomes will not likely improve this situation because earnings under a conformed system will likely be much more conservative in an attempt to save tax dollars (Joos and Lang, 1994). Based on prior research (e.g., Ali and Hwang, 2000), these more conservative earnings will likely be less value relevant than currently reported financial accounting earnings.

34. We note that, in addition to the loss of value relevance of earnings in this case, it is not costless to investors and to the economy to develop other means for firm stakeholders to obtain information about firm performance.

35. Consistent with the international findings, in a U.S. setting, Guenther, Maydew, and Nutter (1997) find that for a unique set of publicly traded firms that were forced to switch for tax purposes from the cash method to the accrual method, requiring the use of the accrual method for tax (conforming taxable income closer to that of financial accounting income) causes firms to defer income (making income more conservative) for financial statement purposes.

36. See Hanlon (2003) for a discussion of the problems in using financial statement information to estimate taxable income and tax liabilities.

37. The authors use the value-weighted market index from CRSP to calculate marketadjusted returns.

38. Consistent with this view, a recent Wall Street Journal article states, "Today's tax code is complicated in part because politicians of both parties are quick to create tax breaks for their favorite causes" (Murray, 2004).

39. If the straight-line method used most often for financial accounting were adopted for taxation purposes, there would be a revenue gain but a loss of a method of providing incentives for investinent behavior. Because additional incentives in excess of MACRS are often provided through depreciation methods (e.g., IRC Section 179 and the bonus depreciation rules following the $9 / 11$ attacks), conforming to financial accounting depreciation would likely entail the greater cost. 
40. Under current GAAP rules, property is recorded at historical cost, and this cost is allocated over the service period of the asset. We note that using the MACRS system for depreciation would be consistent with a more fair value-based approach to which financial accounting is moving in general.

\section{References}

Ali, A., and L. Hwang (2000). "Country Specific Factors Related to Financial Reporting and the Relevance of Accounting Data." Journal of Accounting Research Spring:1-21.

Ball, R., and P. Brown (1968). "An Empirical Evaluation of Accounting Income Numbers." Journal of Accounting Research 6:159-177.

Ball, R., S. P. Kothari, and A. Robin (2000). "The Effect of Institutional Factors on Properties of Accounting Earnings." Journal of Accounting and Economics 29:1-51.

Beaver, W. (1968). "The Information Content of Annual Earnings Announcements." Journal of Accounting Research Supplement:67-92.

Boynton, C., and L. Mills (2004). "The Evolving Schedule M-3: A New Era of Corporate Show and Tell." National Tax Journal 57(3):757-772.

Brown, S., K. Lo, and T. Lys (1999). "Use of $\mathrm{R}^{2}$ in Accounting Research: Measuring Changes in Value Relevance Over the Last Four Decades." Journal of Accounting and Economics 28:83-115.

Carnahan, I., and J. Novack (2002). "Two Birds, One Stone: Would Firms Inflate Earnings if It Meant More Taxes?" Forbes 169(March 2):40.

Choi, W., J. Gramlich, and J. Thomas (1998). "Potential Errors in Detection of Earnings Management: Reexamining the Studies of the AMT of 1986." Columbia University. Working Paper.

Collins, D., E. Maydew, and I. Weiss (1997). "Changes in Value Relevance of Earnings and Book Values over the Past Forty Years." Journal of Accounting and Economics 24:39-67.

Desai, M. A. (2003). "The Divergence Between Book and Tax Income." In Tax Policy and the Economy, vol. 17, James M. Poterba (ed.). Cambridge, MA: MIT Press, 169-206.

Desai, M. A. (2004). "The Degradation of Corporation Profits." Harvard University. Working Paper.

Dhaliwal, D., and S. Wang (1992). "The Effect of Book Income Adjustment in the 1986 Alternative Minimum Tax on Corporate Financial Reporting." Journal of Accounting and Economics 15(1):7-26.

Fama, E., and K. French (2004). "New Lists: Fundamentals and Survival Rates." Journal of Financial Economics 73(2):229-269.

Financial Accounting Standards Board (1992). "Statement of Financial Accounting Standards 109-Accounting for Income Taxes." Norwalk, CT. February.

Financial Accounting Standards Board (1995). "Statement of Financial Accounting Standards 123-Accounting for Stock Based Compensation." Norwalk, CT. October.

Francis, J., and K. Schipper (1999). "Have Financial Statements Lost Their Relevance?" Journal of Accounting Research 37(Autumn):319-352. 
Gramlich, J. (1991). "The Effect of the Alternative Minimum Tax Book Income Adjustment on Accrual Decisions." Journal of the American Taxation Association 13(1):36-56.

Grassley, Charles E. (2002a). "Grassley Release, Letter on Public Disclosure of Corporate Tax Returns." Tax Notes Today 131(July 9):16.

Grassley, Charles E. (2002b). "U.S. Senator Grassley Calls for Review of Corporate Return Disclosure Requirements." Worldwide Tax Daily 198(October 11):30.

Guenther, D., E. Maydew, and S. Nutter (1997). "Financial Reporting, Tax Costs, and Book-Tax Conformity." Journal of Accounting and Economics 23:225-248.

Hamilton, A., and N. Radziejewska (2003). "Olson Argues for Eliminating Some BookTax Reporting Differences." Tax Notes (March 31):1935-1936.

Hanlon, M. (2003). "What Can We Infer About a Firm's Taxable Income from Its Financial Statements?" National Tax Journal 56(December):831-863.

Hanlon, M. (2005). "The Persistence and Pricing of Earnings, Accruals, and Cash Flows When Firms Have Large Book-Tax Differences." The Accounting Review, (January)80:1:137-166.

Hanlon, M., S. Kelley, and T. Shevlin (2005). "Evidence on the Possible Information Loss of Conforming Book Income and Taxable Income." University of Michigan and University of Washington. Working Paper. Forthcoming, Journal of Law and Economics.

Hanlon, M., and T. Shevlin (2002). "The Accounting Treatment of the Tax Benefits of Employee Stock Options: Implications for Financial Accounting and Tax Research." Accounting Horizons 16(1):1-16.

Hayn, C. (1995). "The Information Content of Losses." The Journal of Accounting and Economics 20:125-153.

Hill and Knowlton (2001). Corporate Citizen Watch Survey. http://www .hillandknowlton.com/common/file.php/pg/dodo//hnk_global/binaries/7/HK \%202001\%20Corp\%20Citizen\%20Watch.pdf. July 17, 2001.

Hulse, D. (1996). "The Timing of the Stock Market Reaction to Rifle-Shot Transition Rules." Journal of the American Taxation Association 18:2:57-73.

Joos, P., and M. Lang (1994). "The Effects of Accounting Diversity: Evidence from the European Union." Journal of Accounting Research 32:141-168.

Joos, P., and G. Plesko (2005). "Valuing Loss Firms." Forthcoming, The Accounting Review.

Knott, A., and J. Rosenfeld (2003). "Book and Tax (Part One): A Selected Exploration of Tow Parallel Universes." Tax Notes May:685-899.

Kothari, S. P. (2001). "Capital Markets Research in Accounting." Journal of Accounting and Economics 31:105-231.

KPMG Peat Marwick (1992). "Accounting for Income Taxes. An Analysis of FASB Statement 109." Montvale, NJ: KPMG.

Landsman, W., and E. Maydew (2002). "Has the Information Content of Quarterly Earnings Announcements Declined in the Past Three Decades?" Journal of Accounting Research June:797-808. 
Lenter, D., D. Shackelford, and J. Slemrod (2003). "Public Disclosure of Corporate Tax Return Information: Accounting, Economics, and Legal Perspectives." National Tax Journal 56(December):803-830.

Lev, B., and D. Nissim (2004). "Taxable Income, Future Earnings, and Equity Values." The Accounting Review, 79(October):1039-1074.

Lo, K., and T. Lys (2000). "Bridgming the Gap Between Value Relevance and Information Content." Northwestern University. Working Paper.

Manzon, G., and G. Plesko (2002). "The Relation Between Financial and Tax Reporting Measures of Income." Tax Law Review 55:175-214.

McGill, G., and E. Outslay (2002). "Did Enron Pay Taxes? Using Accounting Information to Decipher Tax Status." Tax Notes 96:1125-1136.

McGill, G., and E. Outslay (2004). "Lost in Translation: Detecting Tax Shelter Activity in Financial Statements." National Tax Journal 57(September):739-756.

Mills, L. (1998). "Book-Tax Differences and Internal Revenue Service Adjustments." Journal of Accounting Research Autumn:343-356.

Mills, L., K. Newberry, and W. Trautman (2002). "Trends in Book-Tax Income and Balance Sheet Differences." Tax Notes 96(8):1109-1124.

Mills, L., and G. Plesko (2003). "Bridging the Reporting Gap: A Proposal for More Informative Reconciling of Book and Tax Income." National Tax Journal 56(December):865-893.

Murray, A. (2002). "Narrowing Tax Gap Should Be Priority of Next Congress." Wall Street Journal October 8:A5.

Murray, S. (2004). "Where's Bush Going on Taxes?" Wall Street Journal September 15:A4.

Plesko, G. (2000). "Book-Tax Differences and the Measurement of Corporate Income." In Proceedings of the Ninety-Second Annual Conference on Taxation, 1999. Washington, D.C.: National Tax Association, 171-176.

Plesko, G. (2002). "Reconciling Corporation Book and Tax Net Income, Tax Years 19961998." SOI Bulletin 21(4):1-16.

Plesko, G. (2004). "Corporate Tax Avoidance and the Properties of Corporate Earnings." National Tax Journal 57(September):729-737.

Scholes, M., M. Wolfson, M. Erickson, E. Maydew, and T. Shevlin (2002). Taxes and Business Strategy: A Planning Approach (2nd edition). Upper Saddle River, NJ: Prentice Hall.

Skinner, D. (2004). "What Do Dividends Tell Us About Earnings Quality?" University of Michigan. Working Paper.

Slemrod, J., and M. Blumenthal (1996). "The Income Tax Compliance Cost of Big Business." Public Finance Quarterly 24(4):411-438.

Stigler, G. (1971). "The Theory of Economic Regulation." Bell Journal of Economics 2(1):3-21.

U.S. Department of the Treasury (1999). "The Problem of Corporate Tax Shelters: Discussion, Analysis and Legislative Proposals." Washington, DC: U.S. Government Printing Office. 
U.S. General Accounting Office (2004). "Comparison of the Reported Tax Liabilities of Foreign- and U.S.-Controlled Corporations, 1996-2000." Washington, DC: U.S. Government Printing Office.

Voung, Q. (1989). "Likelihood Ratio Tests for Model Selection and Non-nested Hypotheses." Econometrica 57:307-333.

Weisman, J. (2002). "At Firms Dual Profit Pictures." Washington Post, October 10, final edition, p. A01.

Yin, G. (2001). "Getting Serious About Corporate Tax Shelters: Taking a Lesson from History." SMU Law Review 54(1):209-237.

Yin, G. (2003). "How Much Tax Do Large Public Corporations Pay? Estimating the Effective Tax Rates of the S\&P 500." Virginia Law Review 89:1793-1797.

Zeff, S. (2002). "'Political' Lobbying on Proposed Standards: A Challenge to the LASB." Accounting Horizons 16:43-54. 